\title{
Assamese Language
}

National Cancer Institute

\section{Source}

National Cancer Institute. Assamese Language. NCI Thesaurus. Code C153840.

An Eastern Indo-Aryan language spoken mainly in the Indian state of Assam. 